| Research Article / Araştırma Makalesi|

\title{
Professional Development Needs Analysis of School Administrators and Teachers in Turkey
}

\section{Türkiye'deki Okul Yönetici ve Öğretmenlerinin Mesleki Gelişim Ihtiyaçlarının Analizi}

\author{
İnayet Aydın ${ }^{1}$, Burcu Toptaş ${ }^{2}$, Ahmet Kaysılı ${ }^{3}$, Güler Tanrıverdi ${ }^{4}$, Nurcan Güngören ${ }^{5}$, Şeyma Topçu ${ }^{6}$
}

Keywords
1. educational
administration and
planning
2. in-service education
3. training needs
assessment
4. professional
development needs
5. teacher development

Anahtar Kelimeler

1. eğitim yönetimi ve planlaması

2. hizmet içi eğitim

3. yetiştirme ihtiyacı analizi

4. mesleki gelişim

ihtiyacı

5. öğretmen geliştirme

Received/Başvuru Tarihi

04.11.2020

Accepted / Kabul Tarihi

24.04.2021

\author{
Abstract \\ Purpose: This study aimed at determining the professional development needs of school administrators and teachers working \\ in Mamak, Ankara and to what extent they needed these trainings were reported in this study.
}

Design/Methodology/Approach: A two-stage path needs analysis model used for the study. First, the nominal group technique was implemented. Second, according to the results, the professional development training needs were turned into targeted surveys for each participant group. The data collected from school administrations and teachers working in Mamak.

Findings: The school administrators need leadership; pre-school teachers need picture analysis; primary school teachers need creative drama; middle-school teachers need integration with the digital world; high-school teachers need first-aid; special education teachers need techniques for changing problematic behaviors, and guidance and psychological counseling teachers need solution-oriented therapy training.

Highlights: The findings have revealed that while school administrators and teachers need core skills related to their fields. They mostly need contemporary training subjects so they can keep up with the times. The training which is commonly needed by the school administrators, pre-school, primary, middle, and high school teachers is first-aid training and the main reasons of this need can be examined in depth through further studies. It was shown in the results that the nominal group results and the surveys differed for all groups. In conclusion, a single needs analysis approach was insufficient for identifying professional development needs, and it is necessary to utilize one or more techniques together. Policymakers and/or practitioners may develop projects and activities, related to the priority subject areas of this study, aimed at improving schools.

öz

Çalışmanın amacı: Bu araştırmanın amacı Ankara'nın Mamak ilçesinde görev yapan okul yöneticileri ile öğretmenlerin mesleki gelişim ihtiyaçlarının belirlenmesi ve bu eğitimlere ne düzeyde ihtiyaç duyduklarının tespit edilmesidir.

Materyal ve Yöntem: İki aşamalı ihtiyaç belirleme tekniğinden yararlanılmıştır. Öncelikle, nominal grup tekniği uygulanmıştır. Sonrasında, elde edilen sonuçlara uygun şekilde her bir katılımcı grubu için ayrı ayrı anketler hazırlanmıştır.

Bulgular: Okul yöneticileri en fazla liderlik; okul öncesi öğretmenleri resim analizi; ilkokul öğretmenleri yaratıcı drama; ortaokul öğretmenleri dijital dünyayla entegrasyon; lise öğretmenleri ilkyardım; özel eğitim öğretmenleri problem davranış değiştirme teknikleri; rehberlik ve psikolojik danışma öğretmenleri çözüm odaklı terapi eğitimlerine ihtiyaç duymaktalardır.

Önemli Vurgular: Araştırma bulgularına göre okul yönetici ve öğretmenlerinin, alanlarının gerektirdiği temel becerilere ihtiyaç duydukları görülmüştür. Buna karşın çağa ayak uydurabilmek adına, en fazla çağdaş yaklaşımlar konusunda kendilerini geliştirmeyi istemektelerdir. Okul yöneticileri, okul öncesi, ortaokul ve lise öğretmenlerinin ortak olarak ihtiyaç duydukları konu ilkyardımdır. Bu durumun temel nedenleri, ileriki araştırmalarla derinlemesine incelenebilir. Bulgular, tüm gruplar açısından anket ve nominal grup çalışmalarından farklı sonuçlar elde edildiğini göstermiştir. Buna göre mesleki gelişim ihtiyaçlarının belirlenmesinde yalnızca bir yaklaşımın yeterli olmadığı anlaşılmaktadır. Bu doğrultuda bir ya da birkaç tekniğin birlikte kullanılması gerekmektedir. Araştırma sonuçlarına uygun şekilde, politika yapıcılar ve/veya uygulayıcılar okulları geliştirmek amacıyla, öncelikli alanlara yönelik projeler ve yetiştirme etkinlikleri geliştirebilirler.

\footnotetext{
${ }^{1}$ Ankara University, Faculty of Educational Sciences, Department of Educational Administration, Ankara, TURKEY; https://orcid.org/ 0000-0002-7522-8961 ${ }^{2}$ Corresponding Author, Ankara University, Faculty of Educational Sciences, Department of Educational Administration, Ankara, TURKEY; https://orcid.org/00000001-8419-7450

${ }^{3}$ Ankara University, Faculty of Educational Sciences, Department of Philosophical, Social and Historical Foundations of Education, Ankara, TURKEY; https://orcid.org/0000-0002-0308-1067

${ }^{4}$ Mamak Provincial Directorate of National Education, Department of Research and Development, Ankara, TURKEY; https://orcid.org/0000-0001-5936-5897

${ }^{5}$ Mamak Provincial Directorate of National Education, Department of Research and Development, Ankara, TURKEY; https://orcid.org/0000-0002-8124-5805

${ }^{6}$ Mamak Provincial Directorate of National Education, Department of Research and Development, Ankara, TURKEY; https://orcid.org/0000-0002-6415-4709
} 


\section{INTRODUCTION}

Teachers are the working input of the school system. They are of vital importance when it comes to improving the quality of education both in terms of individual representation as well as the representation of their occupation (Durkheim, 2016). Since teachers are the implementers of numerous actions within the framework of the macro-policy of the educational system, it can be stated that teachers in a sense constitute the load-bearing columns that support the system itself. On the other hand, school administrators are also an important facet of the educational system and as individuals make decisions required for education institutions to reach specific goals; implement planning processes, organization, and coordination; oversee the division of labor, make cooperation and motivation possible by establishing efficient communication with the educational staff as well as are the people who carry out the performance management of school staff. Therefore, continuous professional development of school administrators who lead teachers is extremely important in terms of both establishing organizational efficiency and making it possible for teachers to work effectively and satisfactorily. Considering this, identification of the professional development needs of school administrators and teachers within the educational system and the planning of trainings which embody the current approaches of education are important. As a result, in this study, two approaches were used to identify the professional development needs of educators, and the results from these findings were presented comparatively.

\section{The Concept of Professional Development}

Each educational system that claims to be successful needs to embody continuous change and transformation to live up to these claims truly. Thus, there is a greater need to rapidly transform teachers' professional efficiency and professional development demands to continue with their occupational practices as well as to adapt to them new conditions. For example, teachers are expected to develop both individually and professionally to meet the requirements of the current age as well as to increase the performance of their institutions (Aydın, 2011a; Omar, 2014). Over time, the professional development process can lead to the transformation of teachers' beliefs and teaching practices, which allows them to focus on changes that will ultimately increase the success of their students' (Martin et al., 2019). From this point of view, professional development can be defined in the most general terms as the development of teacher skills and efficiencies which produce important educational results for students (Hassel, 1999; as cited in Pharis et al., 2019).

Making professional development possible in line with its objectives is possible through a systematic process in which teachers participate and are contemplative. As Aydın (2016) states, the concepts of education and development are the results of a positive approach. Identification of the gaps between existing and required performance with the participation of teachers, and in the process removing these gaps through functional educational programs, is among the most important aspects of professional development. In this respect, the individual first needs to do his/her job well, then a needs analysis should be carried out with a proactive understanding as a way of identifying their future skills and efficiencies. In fact, it would be incorrect to leave teacher development only to teachers. It is both a right of the teachers to receive professional development training to improve themselves and their careers as well as their duty to participate in such training to increase both individual and institutional performance.

Professional development has two main foundations in terms of teachers. These are pre-service training which involves undergraduate study prior to beginning their professional life and in-service training or professional development activities which should continue throughout teachers' careers (Işık, Çiltaş, \& Baş, 2010). While the paradigm regarding pre-service training is "giving training in case it is required", the paradigm reflected by in-service training is "giving training when it is required". It should be pointed out that in-service training is of vital importance in terms of institutional and individual development, regardless of the overall quality of the pre-service training (Aydın, 2011b), because even average in-service training programs can increase the selfefficacy of teachers (Tzivinikou, 2015). In-service training is a process which continues throughout life and should be the cultivation and education of a teacher from the first day of their career until their final day of teaching (Başaran, 1969). According to Aydın (2014), one of the aims of in-service training is to create a learning culture within the school. Importantly, the creation of a learning culture requires the school to be a learning organization. At this point, individuals who are willing to learn, will without a doubt, play an important and helpful role in the creation of this culture.

The idea of neoteric professional development requires teachers to make continuous efforts to participate in, learn from, and institute the skills and efficiencies they acquire. For example, one-off and/or short-term professional development processes are far less effective (Pharis et al., 2019). Instead, teachers' professional development "should be regarded as a continuous, a limitless process which is open to change and development and it should be made possible for teachers to perceive this process as a lifestyle" (Tutkun \& Aksoyalp, 2010, 369). Expecting teachers to continue their professional lives only with their previous knowledge and skills causes the teaching profession to fall behind as a specialty and to decrease the quality of the education system (Kaçan, 2004). Preventing stagnation and decline in educational systems is possible when teachers continuously renew and develop themselves through in-service training and/or professional development activities they attend throughout their careers.

\section{Professional Development Needs Analysis Techniques}

Professional development needs are the gaps that exist between the competencies employees already have and those competencies they need to gain to work effectively and satisfactorily in both the present and future. Needs analysis is a process

| Kastamonu Education Journal, 2021, Vol. 29, No. 21 
that can be utilized to identify the differences between employees' current and expected competencies (Omar, 2014). In this respect, doing needs analysis makes it possible for teachers to receive training that is more suitable and applicable for the structure of their classes (Bayrakçı, 2009). Needs analysis techniques consist of surveys, interviews, focus groups, nominal groups, work analysis as well as performance form observation and documentation (Aydın, 2011a). Each technique has both advantages and disadvantages; therefore, a variety of techniques should be utilized together to identify the appropriate professional development needs of teachers.

The assumption that teachers need training due to specific insufficiencies that they may have led to "centralized, top-down training policies" within professional development programs (Yaylacı, 2013). So, in-service training is generally determined by toplevel administrators who do not consider the individual needs of teachers and instead focus on items that fit their own agenda (National Board Resource Center, 2010; Summey, 2013; as cited in Crompton, Olszewski \& Bielefeldt, 2016). Whereas in the process of doing these analyses, it should be made clear that these trainings are not a wish list, instead they depend on reality rather than assumptions and should not solely reflect the views of administrators (Aydın, 2011a). In fact, teachers can contribute a great deal to the development of trainings as a part of the identification and planning process of in-service training (Campbell \& Kane, 2000; John \& Gravani, 2005). For example, preparing training content without consulting teachers or identifying their needs can result in a program carried out "in an imposed manner, without asking for the demands and views of the teachers" and this situation disenables the activities during the seminar period (Genç \& Aydın, 2015). The teachers who criticize the professional development process express themselves by saying, "It is like we are all being given the same medication regardless of what kind of illness we have!" (National Board Resource Center, 2010, 26). Teachers' negative views regarding seminar period activities are based on their view that they are receiving training that they do not need (ilğan, 2013). However, for an effective professional development to occur, teachers need to "identify targets for themselves, select activities, and participate in the process actively" (Horsley, 2007; as cited in Bümen et al., 2012, 37). In this regard, doing needs analysis for professional development activities that meet the needs of teachers is extremely important in terms of both their willingness to participate in the program as well as making sure these activities reach the targeted level of success and do so in a productive manner.

\section{The In-Service Trainings in Turkey}

The in-service teacher trainings in Turkey is planned both at the school and the ministerial level. Within the body of the Ministry of Education (MoNE) in Turkey, in-service teacher trainings are organized for teachers by the General Directorate of Teacher Training and Development (GDTTD). Since 2001, the GDTTD has regularly published in-service training plans. In the 2019 in-service training plan, it is stated that the GDTTD has organized a total of 344 trainings for educators, of which 35 of these trainings were provided as distance education. When a detailed analysis of the plan was made, there is a wide variety of training intended such as foreign language, project preparation, technological developments (e.g., STEM), and drama education. However, when the number of teachers in Turkey is considered, it can be stated that these trainings are relatively insufficient and that there needs to be an increase in their frequency. For instance, 13 trainings were planned for special education teachers who were actively employed, and 1184 teachers participated in these trainings. When it is considered that 14,043 special education teachers are actively employed throughout Turkey according to the 2018-19 MoNE statistics, only $1 \%$ of the special education teachers were able to participate in the provided trainings. However, this number could increase because during 2020 and the global pandemic (COVID-19) crisis there has been an increase in online teacher training offered by MoNE. Although it is difficult for MoNE to reach all of the teachers throughout Turkey under normal circumstances and during regular school operations, it should be stated that teacher training needs are increased, and in particular, it is increased at the school level to meet the needs of school administrators and teachers from all grade levels.

The period of seminar trainings is the most common practice in teachers' professional development activities in Turkey. These trainings had been conducted twice - at the beginnings and at the ends of each academic year - until the MoNE decided to increase the periods. These seminar trainings for teachers normally take place once at the beginning of the school year and at the end of the academic year. This system of seminar-based teacher training has taken place each year up until the 2019-20 academic year. To carry out these trainings the MoNE has typically given mid-term breaks to students in the months of November and April for five days each time. During this period while students are on break, the school administrators and teachers have to attend the scheduled training seminars. Though this process was interrupted due to the closure of schools during the COVID-19 pandemic, MoNE continues to provide teachers to diversify and develop their professional development activities, and to implement the innovations they gain as well. However, according to ilğan (2013), even in the past decade, seminar period activities which constitute the greatest content of teachers' professional development in Turkey, are quite controversial in terms of their quality. Additionally, teachers define these semester break periods as a "seminar holiday", and as a result, often regard the process merely as a formality (Genç \& Aydın, 2015). In addition, the seminar trainings are often discounted due to the activity reports being disregarded (Tonbul, 2006) as well as the attendees do not always have the freedom to choose which activities are presented during seminar trainings (Bümen et al., 2012). This can be seen as a proof that determining the training needs is not sufficient alone, and that training subjects should be prepared and presented with utmost care is also an important requirement.

Considering these views, the aim of this study is to determine the professional development training needs of school administrators and teachers working in the Mamak district of Ankara in Turkey. It can be seen in the literature that (Ergin, Akseki, 
\& Deniz, 2012; Özdemir, 2010; Şirin \& Coşkun, 2015) the professional development needs of teachers are generally determined through the survey method. In addition, most studies (Akar, 2010; Demirel \& Budak, 2003; Şen, 2011) are only used to evaluate the needs of specific teacher groups. As a result, in this study, two needs analysis techniques were utilized together, which were the nominal group technique and the survey technique. While the nominal group technique allows group members to voluntarily participate by actively stating their views within a democratic environment, the survey technique makes it possible to determine the general tendencies of the larger participant group (Aydın, 2011a). Therefore, this study can contribute to the literature by using two different techniques in combination, thus simultaneously presenting the views of school administrators as well as those of the teacher groups, thus allowing for a comparison of views. In this respect, the aim of this study was to identify the training needs of school administrators and teachers and to what extent these groups needed the identified trainings. Thus, answers to the following research questions were sought:

1. What kind of training do school administrators, pre-school, primary school, middle school, high school, special education, and guidance and psychological counseling teachers need?

2. To what extent do school administrators, pre-school, primary school, middle school, high school, special education, and guidance and psychological counseling teachers need the identified training?

\section{METHOD/MATERIALS}

\section{Research Design}

The study is a descriptive study designed in the survey design. The aim of the survey model is to describe specific dimensions and/or characteristic traits of an analyzed group (Fraenkel, Wallen, \& Hyun, 2012).

\section{The Study Group}

According to the determination of participation regarding needs analysis studies, it was attached importance to achieve maximum variety in terms of gender, school level, seniority and region. The distribution of the participants in the nominal group study is provided in Table 1.

Table 1. Distribution and percentages of school administrators and teachers in the nominal group in line with different variables

\begin{tabular}{|c|c|c|c|c|}
\hline \multirow{12}{*}{$\begin{array}{l}\text { School } \\
\text { Administrators }\end{array}$} & Variable & Group & $N$ & $\%$ \\
\hline & \multirow{3}{*}{ Gender } & Female & 9 & 28.1 \\
\hline & & Male & 23 & 71.9 \\
\hline & & Total & 32 & 100 \\
\hline & \multirow{8}{*}{ Seniority } & $1-5$ & 8 & 25.0 \\
\hline & & $6-10$ & 8 & 25.0 \\
\hline & & $11-15$ & 8 & 25.0 \\
\hline & & $16-20$ & 3 & 9.4 \\
\hline & & $21-25$ & 4 & 12.5 \\
\hline & & 26-30 & 0 & 0 \\
\hline & & 31 and over & 1 & 3.1 \\
\hline & & Total & 32 & 100 \\
\hline \multirow{12}{*}{ Teachers } & Variable & Group & $N$ & $\%$ \\
\hline & \multirow{3}{*}{ Gender } & Female & 118 & 64.5 \\
\hline & & Male & 65 & 35.5 \\
\hline & & Total & 183 & 100 \\
\hline & \multirow{8}{*}{ Seniority } & $1-5$ & 11 & 6.0 \\
\hline & & $6-10$ & 50 & 27.3 \\
\hline & & $11-15$ & 36 & 19.7 \\
\hline & & $16-20$ & 34 & 18.6 \\
\hline & & $21-25$ & 38 & 20.7 \\
\hline & & 26-30 & 10 & 5.5 \\
\hline & & 31 and over & 4 & 2.2 \\
\hline & & Total & 183 & 100 \\
\hline
\end{tabular}

As it can be seen in Table 1, a total of 32 school administrators and 183 teachers participated in the nominal group of this study. Nine of the school administrators were female and 23 were male, while 118 of the teachers were female and 65 were male.

In the second stage of the study, the target population was the school administrators and teachers working in Mamak. The distribution of participants in the second study group in line with different variables is provided in Table 2.

As it can be seen in Table 2, a total of 183 school administrators and 1239 teachers made up the second study group in this study. Overall a total of 6183 teachers and 398 school administrators were employed in Mamak during the period in which this study took place. In the study group, there were 1239 (20\%) teachers and $183(45.9 \%)$ school administrators. Therefore, it can be stated that there was a good level of participation in the professional development needs analysis. 
Table 2. Distribution and percentages of school administrators and teachers in the second study group in line with different variables

\begin{tabular}{|c|c|c|c|c|}
\hline \multirow{23}{*}{$\begin{array}{l}\text { School } \\
\text { Administrators }\end{array}$} & Variable & Group & $N$ & $\%$ \\
\hline & \multirow{3}{*}{ Gender } & Female & 45 & 24.6 \\
\hline & & Male & 138 & 75.4 \\
\hline & & Total & 183 & 100 \\
\hline & \multirow{8}{*}{ Seniority } & $1-5$ & 8 & 4.4 \\
\hline & & $6-10$ & 30 & 16.4 \\
\hline & & $11-15$ & 39 & 21.3 \\
\hline & & $16-20$ & 36 & 19.7 \\
\hline & & $21-25$ & 32 & 17.5 \\
\hline & & $26-30$ & 20 & 10.9 \\
\hline & & 31 and over & 18 & 9.8 \\
\hline & & Total & 183 & 100 \\
\hline & \multirow{6}{*}{$\begin{array}{c}\text { Administrative } \\
\text { Seniority }\end{array}$} & $1-5$ & 104 & 56.8 \\
\hline & & $6-10$ & 32 & 17.5 \\
\hline & & $11-15$ & 19 & 10.4 \\
\hline & & $16-20$ & 11 & 6 \\
\hline & & 21 and over & 17 & 9.3 \\
\hline & & Total & 183 & 100 \\
\hline & \multirow{5}{*}{ School level } & Pre-school & 8 & 4.4 \\
\hline & & Primary school & 50 & 27.3 \\
\hline & & Middle school & 60 & 32.8 \\
\hline & & High school & 65 & 35.5 \\
\hline & & Total & 183 & 100 \\
\hline \multirow{11}{*}{ Teachers } & \multirow{3}{*}{ Gender } & Female & 969 & 78.2 \\
\hline & & Male & 270 & 21.8 \\
\hline & & Total & 1239 & 100 \\
\hline & \multirow{8}{*}{ Seniority } & $1-5$ & 235 & 18.9 \\
\hline & & $6-10$ & 348 & 28.1 \\
\hline & & $11-15$ & 202 & 16.3 \\
\hline & & $16-20$ & 215 & 17.4 \\
\hline & & $21-25$ & 150 & 12.1 \\
\hline & & $26-30$ & 59 & 4.8 \\
\hline & & 31 and over & 30 & 2.4 \\
\hline & & Total & 1239 & 100 \\
\hline
\end{tabular}

\section{The Data Collection Tools and the Collection of Data}

In the first stage of this study, the nominal group technique was applied. Although there are different views regarding the steps of the nominal group technique (Balcl, 2014; Claxton, Ritchie \& Zaichkowsky, 1980), the most acknowledged understanding, which is a technique that consists of four steps that were implemented in this study, is presented by Gepson Martinko, Belina (1981). In this respect in the first step, the participants were asked to successively write down five training subjects that they believed were necessary for their personal and professional development as well as that of their colleagues. In the second step, they were asked to share the identified training subjects with the entire participant group. The participants were expected to share another training subject if their subjects had already been listed. Also, the training subjects shared by participants were numbered according to the order in which they were stated, and these were projected onto a screen. In the third step, the participants were given some time and were asked to choose five of the training subjects they saw listed on the screen and score the subjects from five to one in order of importance for them. In the fourth step, the scores provided by the participants were entered into a spreadsheet software program (e.g., Microsoft Excel) prepared beforehand, and after all the views were stated, the training subjects were ordered according to their degree of importance.

Following the nominal group studies, the school administrators and teachers were sent a survey form which included the training subjects listed within the first stage of the study. This was done to identify the level of need for trainings that had been highlighted by the groups for the larger groups. For example, the participants were expected to score the trainings listed in the survey form according to their personal needs. The survey answer choices consisted of the following: 1 . There is no need at all, 2 . There is a need at a low level, 3 . There is a need at a medium level, and 4 . There is a need at a high level. Importantly, the surveys were sent online to each group separately and the data were obtained in this manner. In addition, for this study, ethical committee approval and application permission from the Ankara Provincial Directorate for National Education were received prior to conducting the study. The professional development needs analysis process is provided in Figure 1. 


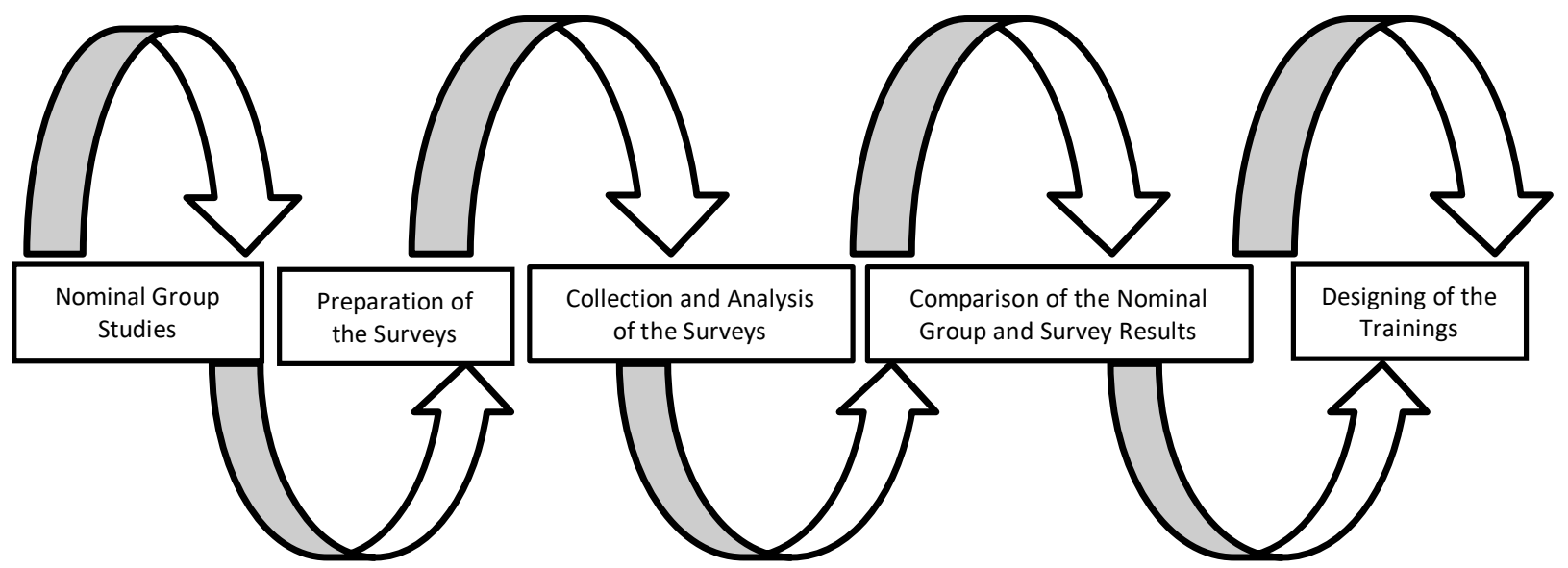

Figure 1. The professional development needs analysis process

\section{The Analysis of the Data}

The data were analyzed under sub-headings for each participant group. In the analysis of the findings, a dual approach was used, and the survey data obtained were evaluated by the comparison of these data with the data obtained through the nominal group technique within the first stage of the study. While the total scores obtained from the participants were calculated in the analysis of the nominal group studies, the arithmetic mean and standard deviation values were calculated in the survey data analysis, and the training subjects that were determined were ordered accordingly.

As mentioned earlier, the nominal group technique was used as a pilot application, in order to ensure that the survey is evaluated both for its suitability for determining the professional development needs of educators, and for its scope. The reason is that the nominal group technique eliminates the possibility of researcher bias in the data analysis (Varga-Atkins, Mclsaac \& Willis, 2017). The ways presented by MacPhail (2001) were followed to assure the internal and external validity of the nominal group technique. Accordingly, the researchers ensured that a) they were present throughout the nominal group process, and $b$ ) participants were included in each step. In terms of ensuring the external validity of the study, the surveys were created to determine the generalizability of the study. The opinions of practitioners and field experts were gained at every stage of the study. The views of field experts, related to the professional development needs obtained by school leaders and teachers, were consulted to test the validity of the study (Taherdoost, 2016). Experts compared and contrasted the training subjects in order to define their similarities and differences, and also for purposes of conformity with the literature. In addition, the surveys were sent to each participant group who was not part of the nominal group, in order to determine the comprehensibility of the surveys. Necessary changes were made according to their views. Since surveys do not measure a structure, Erkuş (2019) states that technical explanations such as the "validity and reliability" of surveys are inaccurate. As a result, the validity and reliability of the surveys in this study have not been assessed.

\section{FINDINGS}

Since it was not practical to present all the training subjects identified through the needs analysis survey, the top 10 most needed training subjects identified according to the survey results were provided. Through the presentation of these findings, the data obtained from the survey and nominal group study were compared. Furthermore, if there is no sequence number for the education title in the nominal group study, it means that the teachers did not give any points for that title.

\section{The Professional Development Needs of School Administrators}

In the nominal group study, the school administrators identified 61 training subjects. For the placement of training subjects in the survey developed based on the nominal group study, the arithmetic mean and standard deviation values for the first 10 training subjects with the highest averages were calculated, and the analysis results are provided in Table 3.

As can be seen in Table 3, the mean of the school administrators' views ranged between $M=2.91$ and $M=3.08$. According to the school administrators' responses regarding their professional development needs; leadership, foreign language, project management, crisis management, first-aid and problem-solving techniques were the trainings stated as being needed at a high level. In the nominal group study, the school administrators stated that they respectively need trainings for crisis management, communication, leadership, conflict management, and protocol and etiquette trainings. Among these trainings though, communication, conflict management, and protocol and etiquette were not listed in the top 10 needed trainings according to the survey results. In addition, the school administrators identified foreign language as a topic of need, which was not scored by school administrators who had participated in the nominal group. 
Table 3. Arithmetic mean and standard deviation values related to the professional development needs of school administrators

\begin{tabular}{|c|c|c|c|c|}
\hline Trainings & $\mathrm{M}$ & SD & $\begin{array}{c}\text { Order of } \\
\text { Importance }\end{array}$ & Nominal \\
\hline 1. Leadership & 3.08 & 1.01 & 1 & 3 \\
\hline 2. Foreign Language & 3.07 & 0.98 & 2 & - \\
\hline 3. Project Management & 3.03 & 0.90 & 3 & 19 \\
\hline 4. Crisis Management & 3.03 & 0.99 & 4 & 1 \\
\hline 5. First-aid Training & 3.01 & 0.96 & 5 & 13 \\
\hline 6. Problem Solving Techniques & 3.01 & 1.01 & 6 & 8 \\
\hline 7. Special Education Applications & 2.98 & 0.90 & 7 & 7 \\
\hline 8. Decision Making Processes & 2.98 & 1.01 & 8 & 19 \\
\hline 9. School Safety & 2.95 & 0.91 & 9 & 15 \\
\hline 10. Basic Law and Administrative Law & 2.95 & 0.91 & 9 & 19 \\
\hline 11. Empathic Communication & 2.91 & 1.02 & 10 & 12 \\
\hline
\end{tabular}

\section{The Professional Development Needs of Pre-School Teachers}

In the nominal group study, 36 training subjects were identified by pre-school teachers. For the placement of training subjects in the survey developed based on the nominal group study, the arithmetic mean and standard deviation values of the first 10 training subjects with the highest averages were calculated, and the analysis results are provided in Table 4.

Table 4. Arithmetic mean and standard deviation values related to the professional development needs of pre-school teachers

\begin{tabular}{|c|c|c|c|c|}
\hline Trainings & M & SD & $\begin{array}{c}\text { Order of } \\
\text { importance }\end{array}$ & Nominal \\
\hline 1. Picture Analysis & 3.53 & 0.74 & 1 & 6 \\
\hline 2. Mind and Intelligence Games & 3.52 & 0.74 & 2 & 7 \\
\hline 3. Creative Drama & 3.49 & 0.74 & 3 & 5 \\
\hline 4. Rhythm Training & 3.44 & 0.77 & 4 & 11 \\
\hline 5. Game Therapy & 3.44 & 0.79 & 5 & 3 \\
\hline 6. First-Aid Training & 3.44 & 0.81 & 6 & 1 \\
\hline 7. Special Education & 3.42 & 0.88 & 7 & 9 \\
\hline 8. Playing a Musical Instrument & 3.37 & 0.83 & 8 & - \\
\hline 9. Robotic Coding & 3.35 & 0.81 & 9 & 8 \\
\hline 10. STEM & 3.35 & 0.83 & 10 & 14 \\
\hline
\end{tabular}

As is seen in Table 4, the mean of the pre-school teachers' views ranged between $M=3.35$ and $M=3.53$. According to the preschool teachers' responses; their needs were greatest in picture analysis, mind and intelligence games, and creative drama trainings. In the nominal group study, pre-school teachers stated that they needed trainings in first-aid, alternative teaching methods, game therapy, developmental tests, and creative drama trainings. Also, it was recognized that alternative teaching methods and developmental tests were not among the top 10 training needs stated by pre-school teachers in the survey results.

\section{The Professional Development Needs of Primary School Teachers}

In the nominal group study, the primary school teachers identified 38 training subjects. For the placement of training subjects in the survey based on the nominal group study, the arithmetic mean and standard deviation values of the top 10 training subjects with the highest averages were calculated, and the analysis results are provided in Table 5.

Table 5. Arithmetic mean and standard deviation values related to the professional development needs of primary school teachers

\begin{tabular}{|c|c|c|c|c|}
\hline Trainings & $\mathrm{M}$ & SD & $\begin{array}{c}\text { Order of } \\
\text { importance }\end{array}$ & Nominal \\
\hline 1. Creative Drama & 3.56 & 0.68 & 1 & 4 \\
\hline 2. Robotic Coding & 3.56 & 0.70 & 2 & 14 \\
\hline 3. Teaching Through Games & 3.53 & 0.69 & 3 & 1 \\
\hline 4. Fun Science Activities & 3.52 & 0.66 & 4 & 11 \\
\hline 5. Mind and Intelligence Games & 3.52 & 0.74 & 5 & 10 \\
\hline 6. Use of Musical Instruments & 3.51 & 0.71 & 6 & 5 \\
\hline 7. Picture Analysis & 3.50 & 0.72 & 7 & 13 \\
\hline 8. Sportive Competence & 3.50 & 0.73 & 8 & 12 \\
\hline 9. First-aid Training & 3.47 & 0.74 & 9 & 7 \\
\hline 10. Use of Technology & 3.47 & 0.81 & 10 & 8 \\
\hline
\end{tabular}

As is seen in Table 5, the mean of the primary school teachers' views ranged between $M=3.47$ and $M=3.56$. According to the primary school teachers' responses, they mostly needed trainings in creative drama, robotic coding, and teaching through games. In the nominal group study, primary school teachers stated that they respectively needed trainings in teaching through games, human relationships and communication in school, child psychology, effective classroom management, and use of musical 
instruments. Also, it was recognized that human relationships and communication in school, child psychology, and effective classroom management were not among the top 10 training needs stated by primary teachers in the survey results.

\section{The Professional Development Needs of Middle School Teachers}

In the nominal group study, the middle school teachers identified 41 training subjects. For the placement of training subjects in the survey developed based on the nominal group study, the arithmetic mean and standard deviation values for the first 10 training subjects with the highest averages were calculated, and the analysis results are provided in Table 6.

Table 6. Arithmetic mean and standard deviation values related to the professional development needs of middle school teachers

\begin{tabular}{|c|c|c|c|c|}
\hline Trainings & M & SD & $\begin{array}{c}\text { Order of } \\
\text { importance }\end{array}$ & Nominal \\
\hline 1. Integration with the Digital World & 3.18 & 0.91 & 1 & 7 \\
\hline 2. Approaches Towards Gifted Children & 3.15 & 0.89 & 2 & 19 \\
\hline 3. Identification of Students with Special Needs and Communication with Them & 3.07 & 0.90 & 3 & 17 \\
\hline 4. Coping with Peer Bullying & 3.07 & 0.98 & 4 & 3 \\
\hline 5. First-Aid Training & 3.06 & 0.98 & 5 & 8 \\
\hline 6. Training to Help Students Acquire Top Level Cognitive Skills & 3.05 & 0.90 & 6 & 18 \\
\hline 7. Foreign Language & 3.03 & 0.96 & 7 & 13 \\
\hline 8. Contemporary Teaching Approaches & 3.02 & 0.92 & 8 & 6 \\
\hline 9. Practices and Approaches Related to Inclusive Students & 3.02 & 0.92 & 8 & 17 \\
\hline 10. Child Psychology & 3.02 & 0.97 & 9 & 4 \\
\hline 11. Stress and Anger Management & 2.98 & 0.98 & 10 & 2 \\
\hline
\end{tabular}

As is seen in Table 6, the mean of the middle school teachers' views ranged between $M=2.98$ and $M=3.18$. According to the middle school teachers' responses, they mostly needed trainings in integration with the digital world, approaches towards gifted children, and identification of students with special needs and communication with them. In the nominal group study, middleschool teachers stated that they respectively need trainings in classroom management, stress and anger management, coping with peer bullying, effective communication with students, and guidance skills. It was recognized that classroom management, effective communication with students, and guidance skills were not among the top 10 training needs stated by middle school teachers in the survey results.

\section{The Professional Development Needs of High School Teachers}

In the nominal group study, high school teachers identified 43 training subjects. For the placement of training subjects in the survey developed based on the nominal group study, the arithmetic mean and standard deviation values of the top 10 training subjects with the highest averages were calculated, and the analysis results are provided in Table 7.

Table 7. Arithmetic mean and standard deviation values related to the professional development needs of high school teachers

\begin{tabular}{|c|c|c|c|c|}
\hline Trainings & M & SD & $\begin{array}{c}\text { Order of } \\
\text { importance }\end{array}$ & Nominal \\
\hline 1. First-aid Training & 3.34 & 0.75 & 1 & 13 \\
\hline 2. Special Education Methods & 3.30 & 0.82 & 2 & 6 \\
\hline 3. Stress and Conflict Management & 3.24 & 0.75 & 3 & 9 \\
\hline 4. Understanding Generation Z & 3.24 & 0.88 & 4 & 16 \\
\hline 5. Motivation Training & 3.20 & 0.82 & 5 & 5 \\
\hline 6. Information on the New Exam System (12 $2^{\text {th }}$ grade) & 3.20 & 0.85 & 6 & 7 \\
\hline 7. Coping with Conflicts between Students (Managing Anger and Mediation) & 3.18 & 0.79 & 7 & 2 \\
\hline 8. New Teaching Methods and Techniques & 3.17 & 0.77 & 8 & 4 \\
\hline 9. Vocational Guidance related to the University Entrance Exam & 3.16 & 0.81 & 9 & 9 \\
\hline 10. Coping with Addictions & 3.11 & 0.79 & 10 & 16 \\
\hline
\end{tabular}

As is seen in Table 7, the mean of the high school teachers' views ranged between $M=3.11$ and $M=3.34$. According to the high school teachers' responses, the trainings that they need most are first-aid, special education methods, stress and conflict management and understanding Generation Z. In the nominal group study, high school teachers stated that they respectively need trainings in values training, coping with conflicts between students, assessment and evaluation, new teaching methods and techniques, and motivation. Also, it was seen that values training, assessment and evaluation, and new teaching methods and techniques were not included within the high school teachers' top 10 training subjects.

\section{The Professional Development Needs of Special Education Teachers}

In the nominal group study, the special education teachers identified 35 training subjects. For the placement of training subjects within the survey based on the nominal group study, the arithmetic mean and standard deviation values of the top 10 training subjects with the highest averages were calculated, and the analysis results are provided in Table 8.

As seen in Table 8, the mean of the special education teachers' views ranged between $M=3.17$ and $M=3.42$. The special education teachers mostly needed trainings in changing problem behaviors, acquisition of language and speech skills for students, 
and behavioral education for students with autism. In the nominal group study with special education teachers, to a certain extent, a variety of different findings were obtained in comparison to other findings within this study. For example, special education teachers stated that they respectively needed trainings in changing problem behaviors, daily life skills, sex education, preparation of individual education programs, and communication skills.

Table 8. Arithmetic mean and standard deviation values related to the professional development needs of special education teachers

\begin{tabular}{|c|c|c|c|c|}
\hline Trainings & $\mathrm{M}$ & SD & $\begin{array}{c}\text { Order of } \\
\text { importance }\end{array}$ & Nominal \\
\hline 1. Changing Problem Behaviors & 3.42 & 0.84 & 1 & 1 \\
\hline 2. Acquisition of Language and Speech Skills for Students & 3.30 & 1.03 & 2 & 6 \\
\hline 3. Behavioral Education for Students with Autism & 3.29 & 0.97 & 3 & 7 \\
\hline 4. Awareness on Special Education Needs of Students & 3.25 & 1.03 & 4 & 13 \\
\hline 5. Family Education & 3.24 & 0.98 & 5 & 10 \\
\hline 6. Social Learning Method & 3.23 & 1.03 & 6 & 9 \\
\hline 7. Puberty Characteristics of Handicapped Individuals & 3.20 & 1.01 & 7 & 11 \\
\hline 8. Sex Education & 3.19 & 1.06 & 8 & 3 \\
\hline 9. Joint Education for Different Handicap Types & 3.17 & 1.00 & 9 & 9 \\
\hline 10. Education for Individuals with Multiple Handicaps & 3.17 & 1.05 & 10 & 14 \\
\hline
\end{tabular}

The Professional Development Needs of Guidance and Psychological Counseling Teachers

In the nominal group study, the guidance and psychological counseling teachers identified 60 training subjects. For the placement of training subjects based on the nominal group study, the arithmetic mean and standard deviation values of the top 10 training subjects with the highest averages were calculated, and the analysis results are provided in Table 9.

Table 9. Arithmetic mean and standard deviation values related to the professional development needs of guidance and psychological counseling teachers

\begin{tabular}{|c|c|c|c|c|}
\hline Trainings & $\mathrm{M}$ & SD & $\begin{array}{c}\text { Order of } \\
\text { importance }\end{array}$ & Nominal \\
\hline 1. Solution Oriented Therapy & 3.27 & 0.95 & 1 & 4 \\
\hline 2. Attention Tests & 3.21 & 0.96 & 2 & 17 \\
\hline 3. Objective Tests Training & 3.17 & 0.98 & 3 & 7 \\
\hline 4. Approaches Related to Raising Psychological Endurance in Students & 3.13 & 0.81 & 4 & 15 \\
\hline 5. Implementation of Positive Psychology in Schools & 3.13 & 0.92 & 5 & 8 \\
\hline 6. Intervention in Cases of Crisis such as Suicide, Death, and Grief & 3.11 & 0.95 & 6 & 10 \\
\hline 7. Game Therapy & 3.11 & 0.99 & 7 & 4 \\
\hline 8. Sex Education for Students Who Need Special Education & 3.10 & 0.96 & 8 & 10 \\
\hline 9. Counseling Skills and Techniques & 3.10 & 1.02 & 9 & 1 \\
\hline 10. Creative Drama & 3.08 & 1.04 & 10 & 12 \\
\hline
\end{tabular}

As is seen in Table 9, the mean of the guidance and psychological counseling teachers' views ranged between $M=3.08$ and $M$ $=3.27$. They stated that the trainings they needed most were solution-oriented therapy, attention tests, and objective tests. In addition, approaches related to raising psychological endurance in students and implementation of positive psychology in schools were other training subjects stated as being needed at a high level. In the nominal group study, teachers stated that they respectively needed trainings in counseling skills and techniques, diagnosis and support of mental, psychological, and behavioral problems, peer-bullying, solution-oriented therapy, and communication skills.

\section{DISCUSSION AND CONCLUSION}

In this study a two-stage path needs analysis model was used to determine the professional development needs of school administrators and teachers working in Mamak as well as to what extent these groups needed the specific types of training they reported through this study. As a result of the data analysis, it was determined that the school administrators stated that they need "crisis management" training the most common within the nominal group study. Ng and Szeto's study (2016) carried out with 32 newly appointed school administrators in which they found similar results to this study findings, that school administrators do not have the competency skills and knowledge for managing crises. The school administrators needed to develop themselves regarding the law, and in this respect, they stated that they need training in the matters of law to be provided by lawyers. In fact, the same was found in this study that the school administrators also stated that they needed training in basic law and administrative law. In addition, Bravender and Staub (2018) state that school administrators new in their careers should be provided crisis management training through simulations to help them make more effective decisions in future crisis situations. Also, the results of Karakuş and Inandı's study (2018) show that school administrators who receive in-service training on crisis management view themselves as more competent in managing crises. This type of training may be more important than ever due to the COVID-19 crisis and the sudden changes experienced by schools during the global pandemic. It should be clear how critical it is for school administrators to receive adequate and effective training in crisis management. 
Another remarkable finding was related to foreign language training which was not scored in the nominal group studies but did rank as the second most important need for school administrators as a part of the survey results. Similarly, this might be related to the project management process which was also highly demanded by school administrators. In fact, it is known that there is an increasing demand for international projects in schools such as European Union funded projects (Kesik \& Balcı, 2016), which could explain for the high demand of foreign language training among school administrators. Therefore, providing foreign language training in line with the preparation, acquisition, and fulfillment of such projects might ultimately satisfy the needs stated by school administrators.

In this study, it was seen that picture analysis and rhythm training which represent new tendencies in pre-school training; mind and intelligence games which aim at developing certain tangible skills of students through games; creative drama; rhythm and game therapy training, were all stated as being the most needed trainings by pre-school teachers. Likely, this reflects the teachers' need for educating their students in line with contemporary tendencies. For example, the most frequently mentioned training needed by pre-school teachers was picture analysis which demonstrated the importance of presenting children with opportunities for expressing things not easily expressed verbally. In addition, Yüksel et al. (2015) state that the use of picture analysis can be beneficial for the learning and development of children. According to Toran and Yağan Güder (2020), pre-school teachers state that they more often participate in training related to their needs; therefore, it can be suggested here that top-level school administrators give priority to the training subjects most desired by teachers. Furthermore, this is important because it appeared from the responses by teachers in this study that they strive to develop their students in a multifaceted manner.

Next, in the dimension of the study related to primary school teachers, it was seen that creative drama and robotic coding were considered as their important needs for teacher training. In addition, primary school teachers stated that teaching through games was also an important professional development need. As shown in the present study findings, contemporary teaching approaches regarding skills such as critical thinking, cooperative learning, efficient use of information and communication technologies, creativity and communication, which are defined as $21^{\text {st }}$ century education skills (Partnership for 21st Century Learning, 2019), were given importance by pre-school and primary school teachers. In terms of primary school teachers, it can be stated that these teachers were up to date in identifying their training needs as well as were aware of the needs for educating students through contemporary means. For example, in a study carried out by the MoNE, Department of Research and Development of Education (2008), it was determined that classroom teachers successively need trainings in areas such as new pedagogic approaches, coping with stress, developing assessment and evaluation tools, education for special education students, teaching through games according to individual student differences, and use of new education technologies. In the time since that study took place, the needs of teachers' have transformed into the use of top-level technological skills such as robotic coding. This is of course related to the expectations of each generation of students that teachers provide education regarding the latest technologies. Therefore, it can be stated that changes which take place over the years need to be matched by the training that teachers currently receive. In this respect, the teachers wish to have training regarding the use of technology in line with the requirements of the current technological needs showed similarities to other studies in the literature (e.g. Ergin, Akseki, \& Deniz, 2012; Fok et al., 2005; Gokmenoglu, Clark, \& Kiraz, 2016).

Furthermore, similarly to the training needs of pre-school and primary school teachers, it was understood that the need of $21^{\text {st }}$ century skills was also a priority of middle-school teachers as well. Clearly, digital competencies have an important place in the interest areas of middle school teachers regarding teaching processes (Aksoy \& Taşkın, 2019). As a result of this study, it was found that integration with the digital world as the highest rated training need according to middle school teachers' responses. Following this, middle school teachers stated that they need trainings for providing a more effective teaching process for the students with special needs. Gokmenoglu, Clark, and Kiraz (2016) also found that teachers need trainings in numerous subjects of teaching students who need special education.

It was a crucial finding of this study that high school teachers stated they mostly need for first-aid training. In addition, firstaid training was listed as the top 10 training subjects needed by school administrators as well as considered important among preschool, primary, and middle school teachers. Importantly, the reason for the greater need by high-school teachers of first-aid training in comparison to other grade levels should be analyzed. In Alikasifoglu et al. (2004), 42\% of the students state that they get into physical fights and some students expressed that these fights end in injuries. Therefore, this professional development need for teachers should be evaluated and more importance be given to violence management within schools. Another important training need for high school teachers is related to preparing students for university placement exam. In Turkey, this exam is an important threshold for individuals to realize vertical mobility within the society. As a result, teachers strive to prepare students to score as possible on the university placement exam so that the students can earn a spot into the best higher-education institutions. Thus, this can be stated as the basis for high school teachers' need of training in motivation, new teaching methods, and techniques as well as arguing for a new and improved university exam system.

Among special education teachers it was recognized from their statements that besides a need for training in behavior management, they also needed training in family education. In Karasu, Aykut, and Yılmaz's study (2014), teachers who are working with mentally handicapped students expressed that they successively need training in teaching methods and approaches, behavior and classroom management, sex education, and family education. According to Konuk Er, Girgin Büyükbayraktar, and Kesici (2016), special education teachers need training about sexuality education for students and handling such issues when they face them. The researchers state that students and graduates of mentally handicapped education express that sex education is an 
extremely important issue in their field (Dedeoğlu, Durali \& Tanrıverdi Kış, 2004). Despite this, it was recognized that sex education is provided within the scope of "Puberty and Sex Education" lessons as an elective course within the special education undergraduate teaching program published by the Higher Education Council (2020). However, due to sex education training being listed among the top 10 training subjects needed by special education teachers, and similar emphasis being made by guidance and psychological counseling teachers the sex education lesson should be a mandatory part of teacher education instead of being an elective course.

The guidance and psychological counseling teachers stated that they mostly needed training in solution-oriented therapy. In fact, it is concluded in studies within the literature (Arslan \& Akın, 2016; Nedim Bal \& Kaya, 2017) that the therapy method is effective in terms of reducing many of the problems that students experience. The guidance and psychological counseling teachers expressed that any application to be made in order to understand the value of their field better is important. In addition, the importance of teachers in-service training is underlined in the literature dealing with the professional development of guidance and psychological counseling teachers (Bengisoy \& Özdemir, 2019). As a result, the training needs of guidance and psychological counseling teachers should be taken into consideration as a guide in terms of the implementation of specific training needs.

Similar to the criticisms directed at professional development studies in different countries, teachers in the seminar period define themselves not as a carrier of knowledge, skills, and experiences, but as passive recipients of the trainings (Quiroz \& Secada 2003; as cited in Passmore \& Hart, 2019). In addition, a professional development program which is provided in a rapid-fire and intense manner because the aim is to present as many subjects as possible within a limited amount of time can cause disappointment and frustration among teachers, which is similar to the feelings administrators and teachers have regarding their professional development expectations (Pharis et al., 2019). However, in an age in which change and transformation take place in such a speedy manner, professional development should become a part of educators' daily activities and should be an inseparable part of school culture (Bubb \& Earley, 2007; as cited in Tuli, 2017). Therefore, as Aydın (2011b) states, a system which handles teachers' in-service training at the central, local, and school levels as well as universities should contribute to this process for all the needs of educational institutions, school administrators, teachers, and students and their families.

In this study, an approach which deals with how and through which processes the needs of school administrators and teachers at the district level can be identified as presented. In this respect, it will be possible to identify the needs of these two important stakeholders within the educational system depending on their personal participation and views as well as the ongoing development of in-service training programs. As these participatory processes are followed, it should allow school administrators and teachers to attend these training activities more often as well as implement what they have learned. Finally, in the findings of this study it was shown that the results of the nominal group study and the surveys differed for all groups who had participated. Therefore, this proves that a single technique is insufficient for professional development needs analysis and that many differing techniques should be utilized in combination to understand better and address this important issue. In future studies, an analysis can be carried out regarding to what extent school administrators and teachers see themselves as adequately trained and qualified in the identified training subjects as well as what level of need exists for these types of training to occur. In addition, it may be possible to conduct in-depth research on the most needed topics in each participant group. For example; it is seen that school administrators need leadership the most. Points, such as what deficiencies they see in themselves regarding leadership, can be determined with surveys/questionnaires to be developed. This study may use a starting point for policymakers to plan trainings based on the need of school leaders and teachers. In accordance with these results, policymakers and/or practitioners may develop projects and activities, related to the priority subject areas of this study, aimed at improving schools. However, this research is limited to the views of school administrators and teachers working in one district of Ankara. Therefore, it includes the views of people working in schools with a similar socio-economic status. For this reason, it may be suggested to apply the surveys more widely.

In conclusion, the aim of this study was to identify the training needs of school administrators and teachers and to what extent these groups needed the identified trainings. The results of the study have enabled a comparison between the educational needs of school leaders and teachers at all levels. The findings have revealed that while school administrators and teachers need core skills (e.g. leadership) related to their fields. They mostly need contemporary training subjects (e.g. foreign language education, communication with the digital world, and robotic coding) to keep up with the times, but most importantly, the school administrators, pre-school, primary, middle and high school teachers all need first-aid trainings. This may explain the current situation of the schools and indicate the necessities of educators in terms of changing behaviors of students. In addition, preschool, primary and the guidance and psychological counseling teachers all need creative drama, which can be used to respond to students' needs in a more engaging manner. Furthermore, it is discovered that the nominal groups and the group to which the survey was applied have different priorities when it comes to professional development needs. This may indicate that the methods by which the majority's views will be obtained need to be followed in order for the trainings need to be planned to be widely accepted.

\section{Declaration of Conflicting Interests}

The authors declare no potential conflicts of interest associated with this research, authorship, and/or publication of this article. 


\section{Statements of Publication Ethics}

The authors hereby declare that the study does not have unethical issues and that the research and publication ethics have been observed carefully.

\section{Author Contribution Statement}

i. A. developed the conception of the study. She was involved in planning and supervising the work. I. A., B. T., and A. K. designed the method of the study as a two-stage path needs analysis. I. A. led the nominal groups. B. T. and A. K. analyzed the nominal group data. G. T., N. G., and Ş. T. collected the survey data and B. T. contributed to the analysis of the survey data. B. T. and A. K. aided in interpreting the data and in drafting the manuscript. All authors discussed the results, commented on the manuscript and approved the final version.

\section{Researchers' Contribution Rate Statement}

The study was conducted and reported with the equal collaboration of the researchers.

\section{Ethics Committee Approval Information}

Ethical committee approval (85434274-050.04.04/40476, no. 5/93) was obtained from Ankara University Research Ethics Committee, Turkey.

\section{REFERENCES}

Akar, E. Ö. (2010). Biyoloji öğretmenlerinin hizmetiçi eğitim ihtiyaçları ve gözlemlenen bölgesel farklılıklar. Eğitim ve Bilim, 32(143), 68-79.

Aksoy, G., \& Taşkın, G. (2019). Öğretim programlarının değişmesini etkileyen faktörlerin, sosyal bilgiler ve fen bilimleri dersi müfredatlarını etkileme boyutu. Milli Eğitim Dergisi, 48(224), 75-99.

Alikasifoglu, M., Erginoz, E., Ercan, O., Uysal, O., Kaymak, D. A., \& Ilter, O. (2004). Violent behaviour among Turkish high school students and correlates of physical fighting. The European Journal of Public Health, 14(2), 173-177.

Arslan, N., \& Akın, A. (2016). Çözüm odaklı kısa süreli grupla psikolojik danışmanın lise öğrencilerinin akran zorbalığına etkisi. Sakarya University Journal of Education, 6(1), 72-84.

Aydın, i. (2011a). Kamu ve özel sektörde hizmet içi eğitim el kitabı. Pegem Akademi.

Aydın, ì. (2011b) Çeşitli ülkelerde öğretmenlerin hizmetiçi eğitimi. Öztürk, C. ve Fındıkçı (Eds.), i. Prof. Dr. Yahya Akyüz'e armağan. Pegem Akademi.

Aydın, ì. (2016). Öğretimde denetim (6. Baskı). Pegem Akademi.

Balcı, A. (2014). Örgütsel gelişme (4. Baskı). Pegem Akademi.

Başaran, İ. E. (1969). Gelişim psikolojisi. Ayyıldız Matbaası.

Bayrakçı, M. (2009). In-service teacher training in Japan and Turkey: A comparative analysis of institutions and practices. Australian Journal of Teacher Education, 34(1), 10-22.

Bengisoy, A., \& Özdemir, M. (2019). Psikolojik danışman/rehber öğretmenlerin bakış açısıyla psikolojik danışma ve rehberlik alanının sorunları. Kıbrıs Türk Psikiyatri ve Psikoloji Dergisi, 1(3), 189-193.

Bravender, M., \& Staub, N. (2018). Using, interactive, problem-based simulations in a mentoring program for novice school leaders. Education Leadership, 19(1), 77-91.

Bümen, N. T., Ateş, A., Çakar, E., Ural, G., \& Acar, V. (2012). Türkiye bağlamında öğretmenlerin mesleki gelişimi: Sorunlar ve öneriler. Milli Eğitim Dergisi, 42(194), 31-50.

Campbell, A., \& Kane, I. (2000). Best of times, worst of times: The importance or otherwise of regular in-servicing. Teacher Development, 4(2), 293-302.

Claxton, J. D., Ritchie, J. B., \& Zaichkowsky, J. (1980). The nominal group technique: Its potential for consumer research. Journal of Consumer Research, 7(3), 308-313.

Crompton, H., Olszewski, B., \& Bielefeldt, T. (2016). The mobile learning training needs of educators in technology-enabled environments. Professional Development in Education, 42(3), 482-501.

Dedeoğlu, S., Durali, S., \& Tanrıverdi Kış, A. (2004). Özel eğitim bölümü zihin engelliler öğretmenliği anabilim dalı 3., 4. sınıf öğrencileri ve mezunlarının kendi bölüm programları, öğretmen yetiştirme ve eğitim fakülteleri ile ilgili düşünce ve önerileri. Ankara Üniversitesi Eğitim Bilimleri Fakültesi Özel Eğitim Dergisi, 5(1), 47-55.

Demirel, Ö., \& Budak, Y. (2003). Öğretmenlerin hizmetiçi eğitim ihtiyacı. Kuram ve Uygulamada Eğitim Yönetimi Dergisi, 9(1), 6281.

Durkheim, E. (2016). Eğitim ve Sosyoloji (Pelin Ergenekon, Çev.). Pinhan Yayıncılık. (Original work published in ...)

Ergin, İ., Akseki, B., \& Deniz, E. (2012). İlköğretim okullarında görev yapan sınıf öğretmenlerinin hizmet içi eğitim ihtiyaçları. Elektronik Sosyal Bilimler Dergisi, 11(42), 55-66. 
Erkuş, A. (2019). Psikolojide ölçme ve ölçek geliştirme I: Temel kavramlar ve işlemler. Pegem Akademi.

Fraenkel, J., Wallen, N., \& Hyun, H. (2012). How to design and evaluate research in education. McGraw-Hill Publications.

Fok, S., Chan, K. W., Sin, K., Heung-Sang Ng, A., \& Yeung, A. (2005). In service teacher training needs in Hong Kong [Paper presentation]. Annual Conference of the Australian Association for Research in Education, Sydney, Australia.

Genç, G., \& Aydın, G. (2015). Mesleki gelişim seminer çalışmalarının öğretmenler tarafından değerlendirilmesi örneklemi. İstanbul Aydın Üniversitesi Eğitim Fakültesi Dergisi, 1(1), 31-69.

General Directorate of Teacher Training and Development [Öğretmen Yetiştirme ve Geliştirme Genel Müdürlüğü] (2019). 2019 yılı öğretmenlerin hizmet içi eğitim planı. http://oygm.meb.gov.tr/meb_iys_dosyalar/2020_02/ 13170757_2019_Ogretmenlerin_Hizmetici_Egitim_Plani.pdf

Gepson, J., Martinko, M. J., \& Belina, J. (1981). Nominal group techniques. Training and Development Journal, $35(9), 78$.

Gokmenoglu, T., Clark, C. M., \& Kiraz, E. (2016). Professional development needs of Turkish teachers in an era of national reforms. Australian Journal of Teacher Education (Online), 41(1), 113-125.

Higher Education Council [Yükseköğretim Kurumu] (2020). Özel eğitim öğretmenliği lisans programı. https://www.yok.gov.tr/Documents/Kurumsal/egitim_ogretim_dairesi/Yeni-Ogretmen-Yetistirme-Lisans-Programlari/ Ozel_Egitim_Ogretmenligi_Lisans_Programi.pdf

Işık, A., Çiltaş, A., \& Baş, F. (2010). Öğretmen yetiştirme ve öğretmenlik mesleği. Atatürk Üniversitesi Sosyal Bilimler Enstitüsü Dergisi, 14(1), 53-62.

ilı̆an, A. (2013). Öğretmenler için etkili mesleki gelişim faaliyetleri. Uşak Üniversitesi Sosyal Bilimler Dergisi, 6(ÖYGE Özel Sayısı), 41-56.

John, P. D., \& Gravani, M. N. (2005). Evaluating a ‘new'in-service professional development programme in Greece: The experiences of tutors and teachers. Journal of In-service Education, 31(1), 105-130.

Kaçan, G. (2004). Sını öğretmenlerinin mesleki gelişime ilişkin isteklilik düzeyleri. Eskişehir Osmangazi Üniversitesi Sosyal Bilimler Dergisi, 5(1), 57-66.

Karakuş, A., \& İnandı, Y. (2018). Ortaokul yöneticilerinin okullarında yaşanan kriz durumlarını yönetme becerilerinin incelenmesi. Mersin Üniversitesi Eğitim Fakültesi Dergisi, 14(2), 500-518.

Karasu, N., Aykut, Ç., \& Yılmaz, B. (2014). Zihin engelliler öğretmenlerinin hizmet içi eğitim ihtiyaçlarının belirlenmesi. Özel Eğitim Dergisi, 15(1), 41-56.

Kesik, F., \& Balcı, E. (2016). AB projelerinin okullara sağladığı katkılar açısından değerlendirilmesi: Bir ölçek geliştirme çalışması. Kastamonu Eğitim Dergisi, 24(4), 1621-1640.

Konuk Er, R., Girgin Büyükbayraktar, Ç. G., \& Kesici, Ş. (2016). Özel eğitime ihtiyacı olan öğrencilere yönelik cinsel eğitim programının geliştirilmesi. Turkish Journal of Education, 5(4), 224-234.

MacPhail, A. (2001). Nominal group technique: a useful method for working with young people. British Educational Research Journal, 27(2), 161-170.

Martin, L. E., Kragler, S., Quatroche, D., \& Bauserman, K. (2019). Transforming schools: The power of teachers' input in professional development. Journal of Educational Research and Practice, 9(1), 179-188.

Ministry of National Education [Milli Eğitim Bakanlığı] (2020). Milli Eğitim istatistikleri, örgün eğitim $2018-2019$. http://sgb.meb.gov.tr/www/icerik_goruntule.php?KNO=361

Ministry of National Education Department of Research and Development of Education [Milli Eğitim Bakanlığı Eğitimi Araştırma ve Geliştirme Dairesi Başkanlığı] (2008). Sınıf öğretmenlerinin hizmet içi eğitim ihtiyacının belirlenmesi. https://www.aol.meb.gov.tr/earged/earged/sinif_ogrt_ihtiyaci.pdf

National Board Resource Center (2010). A quality teacher in every classroom: Creating a teacher evaluation system that works for California. Stanford University.

Nedim Bal, P., \& Kaya, C. (2017). 6. sınıf öğrencilerinin okul tükenmişliği ile baş etmede çözüm odaklı grupla psikolojik danışmanın etkisi. Uluslararası Sosyal Bilimler Dergisi, 10(51), 770-777.

Ng, S. W., \& Szeto, S. Y. E. (2016). Preparing school leaders: The professional development needs of newly appointed principals. Educational Management Administration \& Leadership, 44(4), 540-557.

Omar, C. M. Z. (2014). The need for in-service training for teachers and its effectiveness in school. International Journal for Innovation Education and Research, 2(11), 1-9.

Özdemir, S. M. (2010). Illköğretim öğretmenlerinin alternatif ölçme ve değerlendirme araçlarına ilişkin yeterlikleri ve hizmet içi eğitim ihtiyaçları. Türk Eğitim Bilimleri Dergisi, 8(4), 787-816.

Partnership for 21st Century Learning (2019). P21 framework for 21st century learning. http://static.battelleforkids.org/documents/p21/P21_Framework_Brief.pdf 
Passmore, G. J., \& Hart, S. R. (2019). Conceptualizing a personalized identity-focused approach to teacher professional development: Postulating the realization of reform. Alberta Journal of Educational Research, 65(3), 180-204.

Pharis, T. J., Wu, E. H., Sullivan, S. S., \& Moore, L. (2019). Improving teacher quality: Professional development implications from teacher professional growth and effectiveness system implementation in rural Kentucky high schools. Educational Research Quarterly, 42(3), 29-48.

Şen, B. (2011). Okul öncesi öğretmenlerinin mesleki doyumları ve hizmet içi eğitim ihtiyaçları üzerine bir araştırma (Uşak ili örneği). [Yayımlanmamış doktora tezi]. Selçuk Üniversitesi Sosyal Bilimler Enstitüsü.

Şirin, A. K., \& Coşkun, Y. D. (2015). Analysis of school counselors' continuing education needs. Uluslararası Eğitim Programları ve Öğretim Çalışmaları Dergisi, 5(9), 105-122.

Taherdoost, H. (2016). Validity and reliability of the research instrument; how to test the validation of a questionnaire/survey in a research. https://hal.archives-ouvertes.fr/hal-02546799

Tonbul, Y. (2006). İlköğretim okullarındaki "meslek çalışma" uygulamalarının etkililiği ile ilgili görüşler. Türk Eğitim Bilimleri Dergisi, 4(1), 13-30.

Toran, M., \& Yağan Güder, S. (2020). Supporting teachers' professional development: Examining the opinions of pre-school teachers attending courses in an undergraduate program. Pegem Eğitim ve Öğretim Dergisi, 10(3), 809-868.

Tuli, F. (2017). Teachers professional development in schools: Reflection on the move to create culture of continuous improvement. Journal of Teacher Education and Educators, 6(3), 275-296.

Tutkun, Ö. F., \& Aksoyalp, Y. (2010). 21. yüzyılda öğretmen yetiştirme eğitim programının boyutları. Selçuk Üniversitesi Sosyal Bilimler Enstitüsü Dergisi, 24, 361-370.

Tzivinikou, S. (2015). The impact of an in-service training program on the self-efficacy of special and general education teachers. Problems of Education in the 21st Century, 64(1), 95-107.

Varga-Atkins, T., Mclsaac, J., \& Willis, I. (2017). Focus Group meets nominal group technique: an effective combination for student evaluation?. Innovations in Education and Teaching International, 54(4), 289-300.

Yüksel, M. Y., Canel, N., Mutlu, N., Yılmaz, S., \& Elif, Ç. A. P. (2015). Okul öncesi çağdaki çocukların “iyi” ve "kötü" kavram algılarının resim analizi yöntemiyle incelenmesi. Değerler Eğitimi Dergisi, 13(29), 271-303. 